\title{
Effect of Cadmium Application on Antimicrobial, Antioxidant and Total Phenolic Content of Basil Genotypes
}

\author{
Kürşat Korkmaz'* Ömer Ertürk², Melek Çol Ayvaz ${ }^{3}$, Mehmet Muharrem Özcan", Mehmet Akgün', \\ Ayşegül Kirli ${ }^{4}$, Duygu Odabaş Alver ${ }^{5}$
}

${ }^{1}$ Department of Soil Science and Plant Nutrition, Faculty of Agriculture, Ordu University, Ordu, TURKEY. ${ }^{2}$ Department of Biology, Faculty of Arts and Sciences, Ordu University, Ordu, TURKEY.

${ }^{3}$ Department of Chemistry, Faculty of Arts and Sciences, Ordu University, Ordu, TURKEY.

${ }^{4}$ Department of Field Crops, Faculty of Agriculture, Ordu University, Ordu, TURKEY.

${ }^{5}$ Giresun University, Vocational School of Health Services, Güre Campus, Giresun, TURKEY.

\begin{abstract}
Background: Exposure to heavy metals leads to increase in reactive oxygen species. Plants have many strategies to counteract the toxic effects of heavy metal stress by activating certain intermediary metabolic activities and making physiological adjustments. Objective: This study was designed to determine total phenolic contents and antimicrobial and antioxidant activities of eight Ocimum basilicum L. genotypes grown in a soil exposed to cadmium at different levels. Methods: Total phenolic contents were calculated as gallic acid equivalent. Antioxidant activity was studied based on DPPH free radical scavenging activity. Antimicrobial activity was determined by disc diffusion method against several microorganisms. Results: The highest antimicrobial activity was observed in the case of genotype 5 against Bacillus subtilus with the inhibition diameter value as $18.50 \mathrm{~mm}$ for basil grown at $\mathrm{Cd}$ free soil. This value just decreased to $17.57 \mathrm{~mm}$ at the conditions with $40 \mathrm{mg} / \mathrm{kg} \mathrm{Cd}$. Depending on increase at cadmium dose, the best grade increase in antimicrobial activity was also observed against B.subtilus for genotype 7 . Total phenolic content and DPPH radical scavenging activity values were also increased with the $\mathrm{Cd}$ application at low doses. At very high doses of $\mathrm{Cd}$ a little decrease was observed for these values. Both of the phenolic content values and DPPH scavenging activities reached their maximum values for genotypes 1,7 and 8 grown at soil exposed to $20 \mathrm{mg} /$ $\mathrm{kg} \mathrm{Cd}$. Conclusion: Although cadmium is toxic, known beneficial properties of the basil samples have not deteriorated. These improved results are due to resistance of the basil plant to survive on adverse conditions.
\end{abstract}

Key words: Cadmium toxicity, Free radical scavenging activities Ocimum basilicum L.

\section{INTRODUCTION}

Plants resources have been used for several purposes such as medicine, food supplements or cosmetic thanks to their functional ingredients. ${ }^{1}$ One of the plants used for this purpose is basil. Basil (Ocimum basilicum L.), a member of the Lamiaceae family, is an annual herb which grows in several regions around the world and widely used as one of the most important industrial and pharmaceutical crops due to its healthy properties. ${ }^{2}$ It has many antioxidant substances responsible for these characteristics. ${ }^{3}$ As known, one of the heavy metals, cadmium (Cd) is highly toxic for environment and human. ${ }^{4}$ Plant cells growing in soil containing $\mathrm{Cd}$ are damaged by imbalance between reactive oxygen species (ROS) and protective systems of cells. Fortunately, plants have developed a range of protective systems to overcome of this situation. ${ }^{5}$ An increase in the activity of the enzymes involved in the metabolism of phenolic compounds when plants are
Submission Date: 30-08-2016; Revision Date: 17-11-2016; Accepted Date: 23-11-2016

DOI: 10.5530/ijper.52.4s.84 Correspondence: Kürşat Korkmaz,

Department of Soil Science and Plant Nutrition, Faculty of Agriculture, Ordu University, Ordu, TURKEY.

Phone: +904522347098 E-mail: korkmaz60@odu. edu.tr

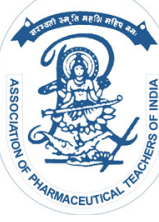

www.ijper.org 
exposed to heavy metal stress has been reported. ${ }^{6}$ Recently, a few researchers have studied that effects of $\mathrm{Cd}$ on free radical scavenging activities in plant. ${ }^{7,8} \mathrm{On}$ the other hand, as far as we know, there are only a few studies reporting the effects of $\mathrm{Cd}$ on the activity of free radical scavenging and antimicrobial activities of basil genotypes. Thus, the aim of the present study was to investigate the effects of $\mathrm{Cd}$ presence at different degrees in soil used for growing basil to its defense system in terms of total phenolic content, antioxidative and antimicrobial activity.

\section{MATERIALS AND METHODS}

\section{Growing of plant materials}

A greenhouse experiment was conducted at the Department of Soil Science and Plant Nutrition, Faculty of Agriculture, Ordu University in Turkey. The treatments consisted of six Cd levels $(0,2.5,5,10,20$ and $40 \mathrm{mg} / \mathrm{kg})$, through application of cadmium sulfate, and eight local basil genotypes. A completely randomized design was used in a factorial arrangement with treatments replicated three times during May through June. Basil genotypes were harvested after 58 days after transplanting at full bloom stage by cutting at 5 - $\mathrm{cm}$ above the soil surface.

\section{Preparation of plant extracts}

The cut slices of Ocimum basilicum L., were air dried and then, aproximately $1 \mathrm{~g}$ of each dried sample was soaked in $5 \mathrm{ml}$ of $90 \%$ ethanol and allowed to shake for $24 \mathrm{~h}$ at room temperature. They were filtered through $0.45 \mu \mathrm{m}$ milipore membrane filter. The filtrates were evaporated. The crude dry extracts were stored at $4{ }^{\circ} \mathrm{C} .{ }^{9}$ Stock solution was prepared by dissolving each dry extract in ethanol. ${ }^{10}$

\section{Bacterial strains and growth conditions}

Antimicrobial activity of the samples was studied against Pseudomonas aeruginosa ATCC $\AA 27853$, Escherichia coli ATCC®25922, Klebsiella pneumoniae ATCC $® 13883$, Listeria monocytogenes ATCC ${ }^{17677, ~ B a c i l l u s ~ s u b t i l i s ~}$ B209, Staphylococcus aureus ATCC 6538 and Candida albicans ATCC®1023. Mueller Hinton Agar (MHA, Merck) or Mueller Hinton Broth (MHB, Merck) and Sabouraud Dextrose Broth (SDB, Difco) or Sabouraud Dextrose Agar (SDA, Oxoid) were used for growing of bacterial and fungal cells, respectively.

\section{Antimicrobial Activity Assay}

Antimicrobial activity of the samples was tested according to disc diffusion method followed by Ronald. ${ }^{11}$ For fungi Nystatin and for bacteria Ampicillin and Cephazolin were used as a positive control. Alcohol was also used as negative control. Inhibition zones which formed on the medium were measured in millimeter $(\mathrm{mm})$ after incubation for $24 \mathrm{~h}$ at $37^{\circ} \mathrm{C}$ and $27^{\circ} \mathrm{C}$ for antibacterial and antifungal activities, respectively. All tests were made in triplicate.

\section{Determination of total phenolic contents}

The phenolic content of the ethanol extracts of basil genotypes was assayed according to the Folin-Ciocalteu method modified by Singleton and Rossi ${ }^{12}$ and expressed as gallic acid (mg GA/100 g dry extract) equivalent.

\section{Measurement of DPPH free radical-scavenging activity}

DPPH free radical scavenging activity of the samples was calculated by following the reduction in the absorbance (at $517 \mathrm{~nm}$ ) of DPPH solution in methanol with the addition of each tested sample. DPPH radical scavenging activities were expressed as inhibition $\%$ for 100 $\mathrm{mg} / \mathrm{ml}$ extract.

\section{Statistical analysis}

All the data analysis was performed using SPSS 20.0 for Windows software (SPSS Inc., NY, USA). The data were statistically analyzed with Levene's test and Shapiro Wilk test for equality of variances and the normality assumption, respectively $(P<0.05)$. Then, the data (diameter of the inhibition zones, DPPH and total phenolic values) were analyzed using 2-way ANOVA and Tukey HSD multiple comparison test for determining any further differences among the groups (genotype and doses). The data (Ampicilin, Cephazolin, Nystatin and Solvents) were also analyzed using One-way ANOVA and Tukey HSD multiple comparison test for determining any further differences among the groups (bacteria). Data were presented as mean with standard deviation. A level of $p<0.05$ was accepted as statistically significant.

\section{RESULTS AND DISCUSSION}

Antimicrobial activities of the basil genotypes varied. The highest measurements were obtained against E. coli and B. subtilus for cadmium free basil samples. On the other hand, for samples grown at the soil not exposed to $\mathrm{Cd}$, the most effective genotypes were 5 and 8 . Cadmium application did not adversely affect antimicrobial activity of the basil grown.

On the contrary, antimicrobial activities of almost all genotypes were increased with cadmium increase. This non-decreasing or increasing activity could be attributed to their ability to synthesize several newly substances, the majority of which may be phenols or oxygensubstituted derivatives. ${ }^{1}$ Most significant declines depending on increased cadmium ratio were observed in the 


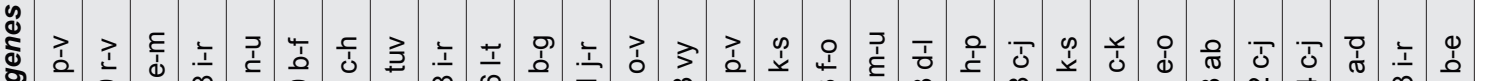
ஓ)

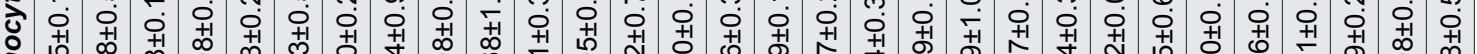
م

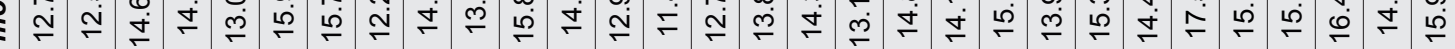

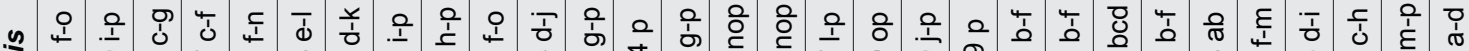

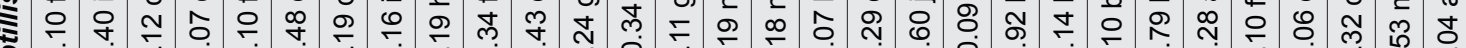

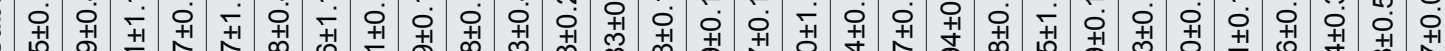
它

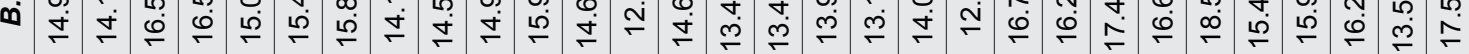

紊烍

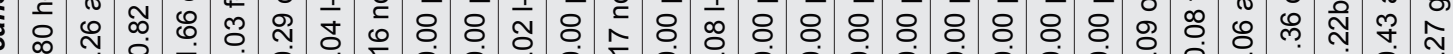

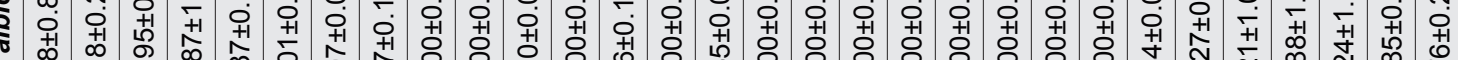

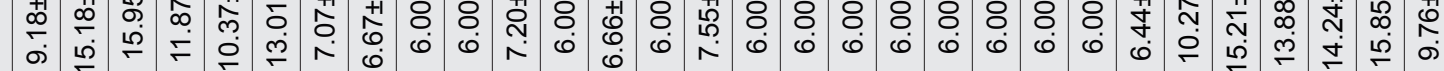

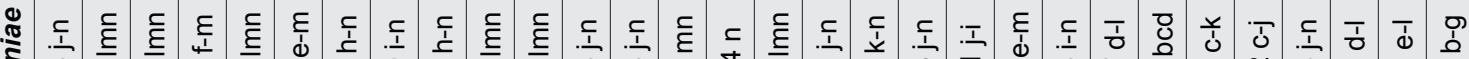

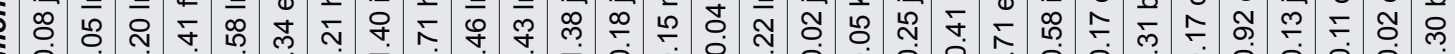

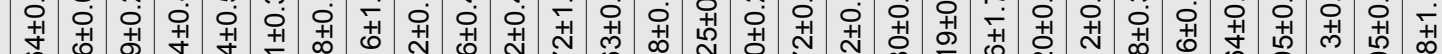

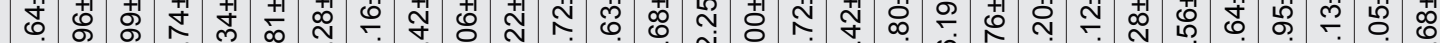

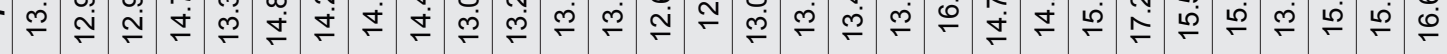

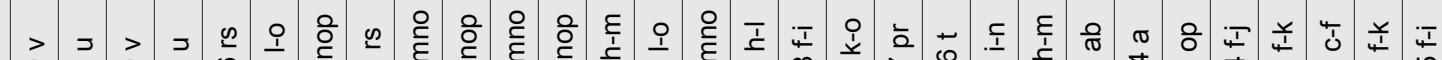

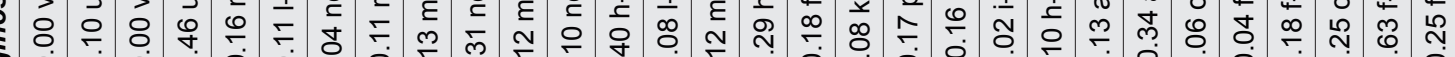

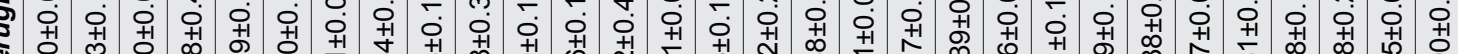

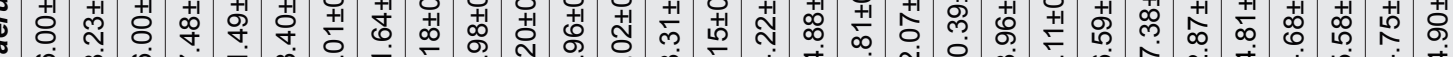

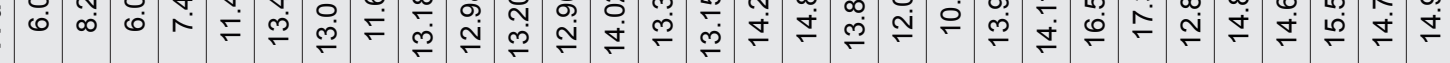

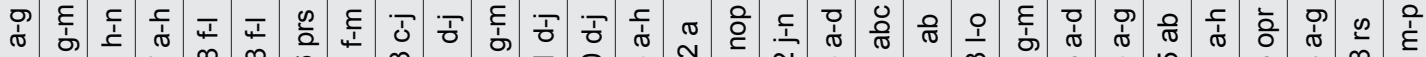

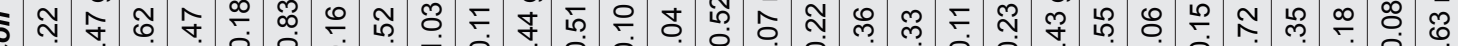

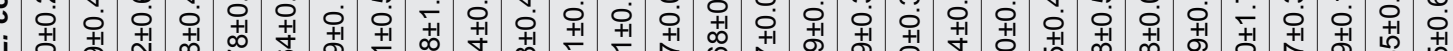

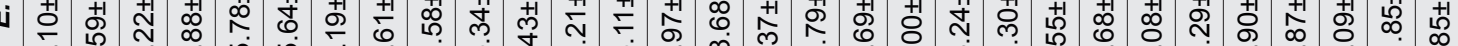

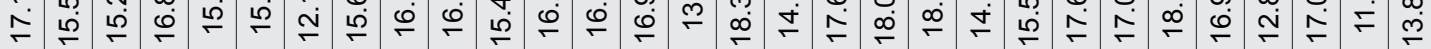

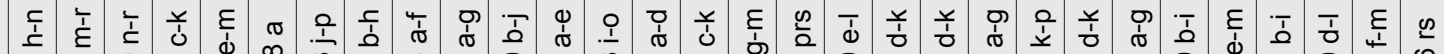

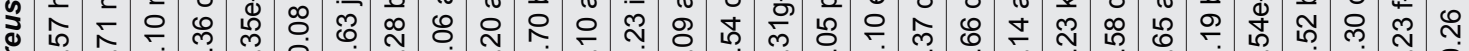

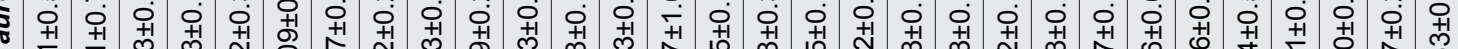

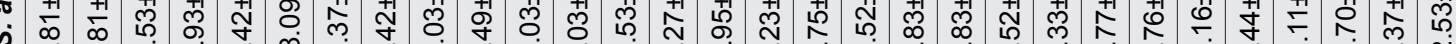

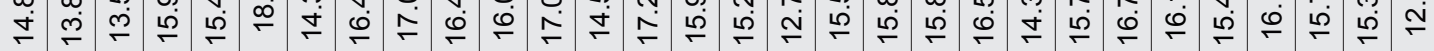

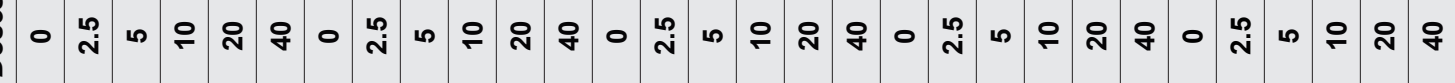




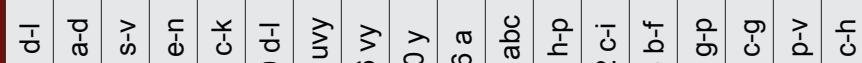
F

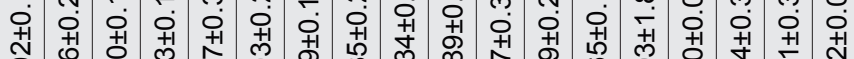

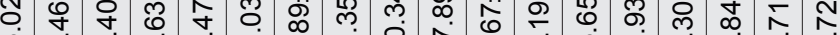

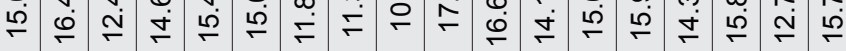

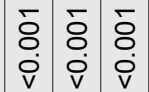

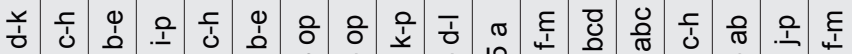

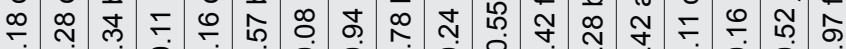

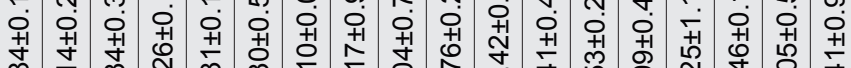

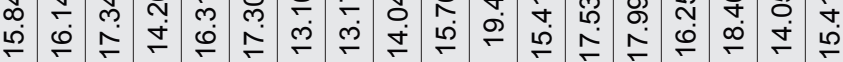

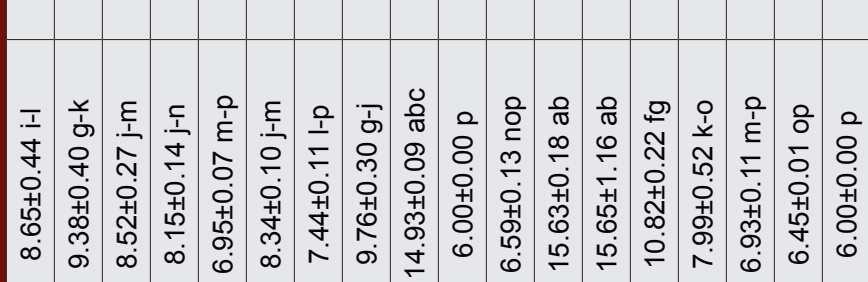

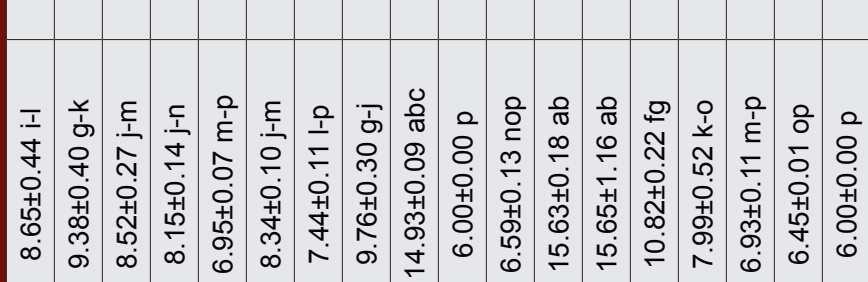

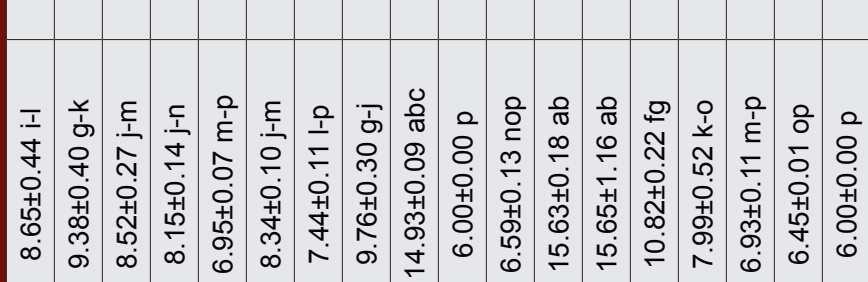

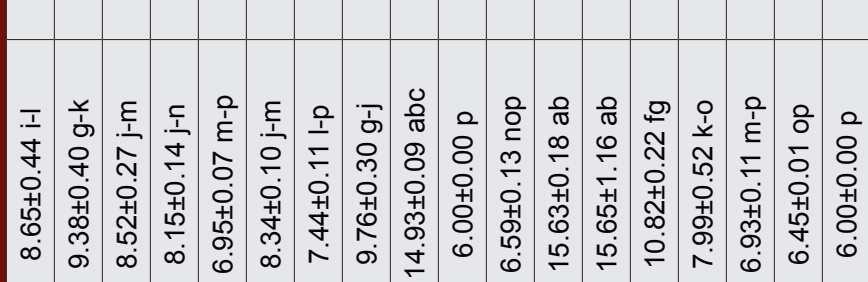

$\begin{array}{lll}\bar{\delta} & \overline{8} & \overline{8} \\ \dot{0} & \dot{0} \\ \dot{v} & \dot{v} \\ v & & \end{array}$ \begin{tabular}{l|l|l|}
$\bar{\delta}$ & $\bar{\delta}$ & $\bar{\delta}$ \\
$\dot{q}$ & $\dot{v}$ & $\dot{v}$ \\
$v$ & $v$ & $v$
\end{tabular} 丁

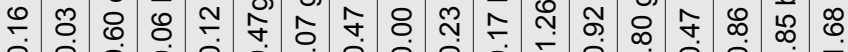

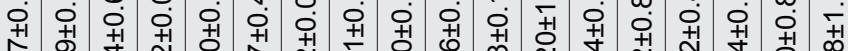

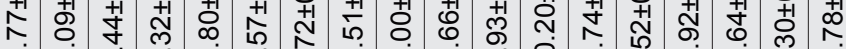

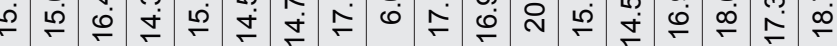

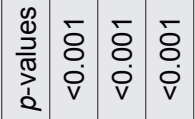

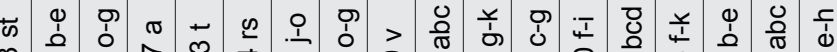

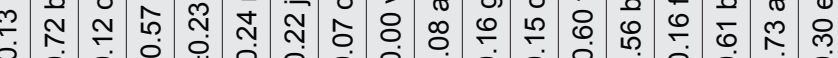

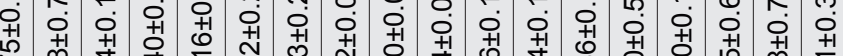

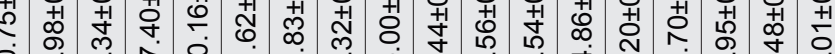

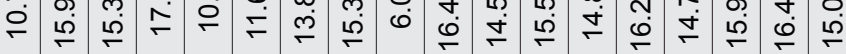

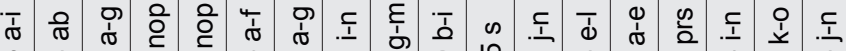
م)

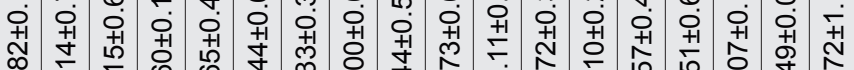

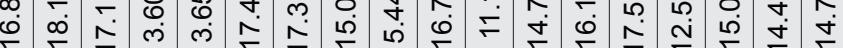

\begin{tabular}{l|l|l}
$\overline{8}$ & $\overline{8}$ & $\overline{8}$ \\
$\dot{0}$ & $\dot{0}$ & 0 \\
$v$ & $\mathbf{v}$ &
\end{tabular}

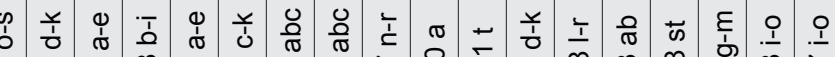
m

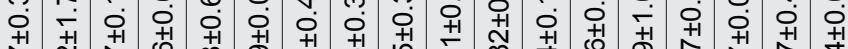

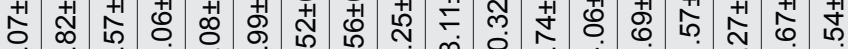
ஹ่

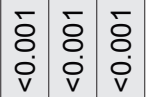

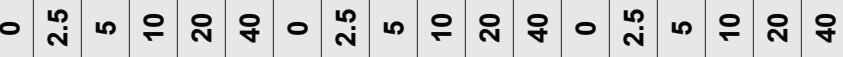

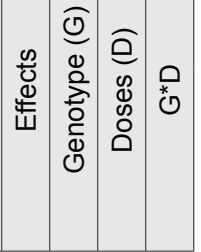


presence of genotypes 5 against $S$. aureus and E. coli and genotype 8 against $C$. albicans. Among the eight genotypes grown at soil exposed to highest $\mathrm{Cd}$ level, genotype 7 had the highest antimicrobial activity against $K$. pneumoniae. To show the change in antioxidant activity of basil species depending on the amount of cadmium in the soil the DPPH radical scavenging activities of the samples were assayed, and the results were expressed as inhibition $\%$.

As seen from Table 2, the lowest and the highest inhibition rates were obtained for genotype 4 and 2, respectively. However, for genotype 4, as the amount of cadmium in the soil increased, the inhibition values increased. No significant change has been observed for genotype 2. In accordance with the literature, in the presence of most of the genotypes, at low doses of $\mathrm{Cd}$, DPPH scavenging activity has been increased, but at high doses of $\mathrm{Cd}$ the activity has begun to fall. ${ }^{13}$

Phenolic compounds have numerous pharmacological properties and amount and types of phenolics depends on several factors such as genetic, environmental and others. ${ }^{14}$ Heavy metal pollution is one of the environmental conditions that affect phenolics. ${ }^{13}$ Therefore the phenolic contents of the samples were also investigated, and interesting results emerged. At even high doses (10 or $20 \mathrm{mg} / \mathrm{kg}$ ) of $\mathrm{Cd}$ presences in soil, the phenolic contents of basil genotypes (1, 3, 4, 7 and 8$)$ have been found as higher than basil genotype grown in $\mathrm{Cd}$ free soil. This situation is attributed that when a plant sample subjected to abiotic conditions such as heavy metals, physiological disorders raised. In such a case, plants have evolved many strategies to counteract the toxic effects by activating certain intermediary metabolic activities and making physiological adjustments. Thus, increase in the amount of phenolic substances is expected. As seen from Table 2 and 3 the increase rates of the phenolic contents and the DPPH radical scavenging activities were similar depending on $\mathrm{Cd}$ doses.

$\begin{gathered}\text { Table 2: Mean diameter }(\mathbf{m m}) \text { of inhibition zones by the positive and negative controls because of } \\
\text { antimicrobial activity according to disc diffusion method. }\end{gathered}$
\begin{tabular}{|c|c|c|c|c|c|}
\hline Bacteria & Ampicilin & Cephazolin & & Nystatin & Solvents \\
\hline S. aureus & $1.00 \pm 0.00 \mathrm{~d}$ & $6.00 \pm 0.00$ & $\mathrm{f}$ & $0.10 \pm 0.00$ & $0.10 \pm 0.00$ \\
\hline E. coli & $0.10 \pm 0.00 \mathrm{e}$ & $15.00 \pm 0.00$ & $\mathrm{~d}$ & $0.10 \pm 0.00$ & $0.10 \pm 0.00$ \\
\hline P. aeruginosa & $29.27 \pm 0.46 \mathrm{~b}$ & $24.33 \pm 0.29$ & $\mathrm{C}$ & $0.10 \pm 0.00$ & $0.10 \pm 0.00$ \\
\hline K. pneumoniae & $13.27 \pm 0.23 \mathrm{c}$ & $11.00 \pm 0.00$ & $\mathrm{e}$ & $0.10 \pm 0.00$ & $0.10 \pm 0.00$ \\
\hline C. albicans & $0.10 \pm 0.00 \mathrm{e}$ & $0.10 \pm 0.00$ & $\mathrm{~g}$ & $15.00 \pm 0.00$ & $0.10 \pm 0.00$ \\
\hline B. subtillis & $35.60 \pm 0.00 \mathrm{a}$ & $38.27 \pm 1.10$ & $\mathrm{a}$ & $0.10 \pm 0.00$ & $0.10 \pm 0.00$ \\
\hline L. monocytogenes & $35.40 \pm 0.35 \mathrm{a}$ & $35.17 \pm 0.40$ & $\mathrm{~b}$ & $0.10 \pm 0.00$ & $0.10 \pm 0.00$ \\
\hline P-values & $<0.001$ & $<0.001$ & & - & - \\
\hline
\end{tabular}

\begin{tabular}{|c|c|c|c|c|c|c|}
\hline \multirow{3}{*}{ Genotype } & \multicolumn{6}{|c|}{ Cd Doses (mg/kg) } \\
\hline & 0 & 2.5 & 5 & 10 & 20 & 40 \\
\hline & \multicolumn{6}{|c|}{ DPPH free radical scavenging activities (inhibition ratio of $100 \mathrm{mg} / \mathrm{ml}$ extract) } \\
\hline 1 & $60.3 \pm 1.44 \mathrm{~g}-\mathrm{k}$ & $64.0 \pm 0.00 \mathrm{c}-1$ & $62.7 \pm 0.00$ e-j & $61.6 \pm 0.00 \mathrm{e}-\mathrm{k}$ & $66.2 \pm 0.00 \mathrm{~b}-\mathrm{h}$ & $54.2 \pm 4.94 \mathrm{j}-\mathrm{m}$ \\
\hline 2 & $91.0 \pm 0.18$ a & $90.1 \pm 1.17$ a & $91.7 \pm 0.00 \mathrm{a}$ & $90.8 \pm 0.00 \mathrm{a}$ & $91.6 \pm 0.00 \mathrm{a}$ & $88.6 \pm 0.00 \mathrm{a}$ \\
\hline 3 & $57.2 \pm 0.00 \mathrm{~h}-\mathrm{I}$ & $49.5 \pm 0.00 \mathrm{Imn}$ & $47.5 \pm 0.00 \mathrm{mn}$ & $64.4 \pm 0.00$ b- I & $58.9 \pm 0.00 \mathrm{~g}-\mathrm{k}$ & $55.8 \pm 0.001-m$ \\
\hline 4 & $28.5 \pm 0.36 p$ & $33.6 \pm 2.52 p$ & $34.6 \pm 0.00 p$ & $52.4 \pm 3.06$ k-n & $48.1 \pm 0.54 \mathrm{Imn}$ & $36.0 \pm 6.56$ op \\
\hline 5 & $84.2 \pm 6.29 a$ & $86.1 \pm 4.41 \mathrm{a}$ & $89.6 \pm 0.00 \mathrm{a}$ & $88.3 \pm 0.32 \mathrm{a}$ & $86.0 \pm 1.80 \mathrm{a}$ & $85.0 \pm 1.80 a$ \\
\hline 6 & $72.3 \pm 0.00 \mathrm{bcd}$ & $70.0 \pm 0.00$ b-f & $67.1 \pm 0.00 \mathrm{~b}-\mathrm{g}$ & $64.1 \pm 0.00 \mathrm{c}-1$ & $67.2 \pm 0.00 \mathrm{~b}-\mathrm{g}$ & $70.8 \pm 0.00 \mathrm{~b}-\mathrm{e}$ \\
\hline 7 & $73.0 \pm 1.08 \mathrm{bc}$ & $60.8 \pm 4.68 \mathrm{f}-\mathrm{k}$ & $61.4 \pm 5.30 \mathrm{f}-\mathrm{k}$ & $73.4 \pm 0.63 b$ & $83.7 \pm 2.16 \mathrm{a}$ & $73.4 \pm 0.00 \mathrm{~b}$ \\
\hline 8 & $44.9 \pm 1.17$ no & $59.8 \pm 3.78 \mathrm{~g}-\mathrm{k}$ & $61.1 \pm 0.00 \mathrm{f}-\mathrm{k}$ & $63.2 \pm 0.25 \mathrm{~d}-\mathrm{j}$ & $68.1 \pm 0.14 \mathrm{~b}-\mathrm{g}$ & $64.3 \pm 0.34 \mathrm{~b}-1$ \\
\hline Effects & \multicolumn{2}{|c|}{ Genotype (G) } & \multicolumn{2}{|c|}{ Doses (D) } & \multicolumn{2}{|c|}{$G * D$} \\
\hline$P$-values & \multicolumn{2}{|c|}{$<0.001$} & \multicolumn{2}{|c|}{$<0.001$} & \multicolumn{2}{|c|}{$<0.001$} \\
\hline
\end{tabular}




\begin{tabular}{|c|c|c|c|c|c|c|}
\hline \multirow[b]{2}{*}{1} & \multicolumn{6}{|c|}{ Total phenolic content (mg GA/100 g dry extract) } \\
\hline & $293.8 \pm 26.73 \mathrm{k}-\mathrm{t}$ & $329.8 \pm 0.00$ h-n & $322.4 \pm 29.32$ I-n & $320.0 \pm 8.62 \mathrm{I}-\mathrm{n}$ & $346.8 \pm 0.00 \mathrm{~d}-\mathrm{m}$ & $313.9 \pm 0.00 \mathrm{j}-\mathrm{o}$ \\
\hline 2 & $493.1 \pm 0.12 \mathrm{a}$ & $472.2 \pm 0.31 \mathrm{abc}$ & $529.1 \pm 16.38$ a & $478.3 \pm 0.38 a b$ & $480.0 \pm 1.40 a b$ & $477.7 \pm 0.50 \mathrm{ab}$ \\
\hline 3 & $239.9 \pm 1.20 \mathrm{p}-\mathrm{u}$ & $239.4 \pm 1.92 \mathrm{r}-\mathrm{u}$ & $237.1 \pm 0.03 \mathrm{stu}$ & $312.1 \pm 25.01 j-p$ & $278.5 \pm 17.25 \mathrm{~m}-\mathrm{t}$ & $229.1 \pm 26.73 \mathrm{stu}$ \\
\hline 4 & $192.0 \pm 0.00 \mathrm{u}$ & $195.0 \pm 11.21 \mathrm{u}$ & $231.6 \pm 9.49 \mathrm{stu}$ & $267.6 \pm 0.00 \mathrm{n}-\mathrm{t}$ & $244.4 \pm 3.45$ o-u & $175.5 \pm 6.04 \mathrm{u}$ \\
\hline 5 & $410.2 \pm 1.72 b-f$ & $389.5 \pm 0.00 \mathrm{~d}-\mathrm{i}$ & $400.5 \pm 51.74 \mathrm{c}-\mathrm{g}$ & $404.1 \pm 24.15 \mathrm{c}-\mathrm{g}$ & $413.9 \pm 0.00 \mathrm{bcd}$ & $411.4 \pm 0.04 \mathrm{~b}-\mathrm{e}$ \\
\hline 6 & $374.3 \pm 12.93 \mathrm{~d}-\mathrm{j}$ & $311.5 \pm 8.62 \mathrm{j}-\mathrm{r}$ & $301.1 \pm 11.21 \mathrm{k}-\mathrm{s}$ & $324.9 \pm 0.00$ I-n & $335.9 \pm 10.35 \mathrm{~g}-\mathrm{n}$ & $382.2 \pm 25.87 \mathrm{~d}-\mathrm{j}$ \\
\hline 7 & $324.4 \pm 0.62 \mathrm{I}-\mathrm{n}$ & $339.5 \pm 39.67$ e-n & $344.2 \pm 0.28 \mathrm{~d}-\mathrm{m}$ & $345.3 \pm 0.43 \mathrm{~d}-\mathrm{m}$ & $399.9 \pm 0.86 \mathrm{c}-\mathrm{g}$ & $332.2 \pm 32.77 \mathrm{~g}-\mathrm{n}$ \\
\hline 8 & $224.9 \pm 1.72 \mathrm{tu}$ & $288.3 \pm 34.49 \mathrm{l}-\mathrm{t}$ & $338.3 \pm 29.32 f-n$ & $351.1 \pm 2.59 \mathrm{~d}-\mathrm{I}$ & $363.3 \pm 26.73 \mathrm{~d}-\mathrm{k}$ & $337.1 \pm 18.97 \mathrm{~g}-\mathrm{n}$ \\
\hline Effects & \multicolumn{2}{|c|}{ Genotype (G) } & \multicolumn{2}{|c|}{ Doses (D) } & \multicolumn{2}{|c|}{$G^{*} D$} \\
\hline$P$-values & \multicolumn{2}{|c|}{$<0.001$} & \multicolumn{2}{|c|}{$<0.001$} & \multicolumn{2}{|c|}{$<0.001$} \\
\hline
\end{tabular}

\section{CONCLUSION}

Cultivation of basil genotypes in cadmium exposed soil did not cause a significant reduction in total phenolic contents, antioxidant and antimicrobial activities, that would affect the pharmaceutical properties the plant. The conclusion that, to sustain life activities defense system of the plant becomes more effective under adverse conditions.

\section{ACKNOWLEDGEMENT}

This work was supported by BAP (AR-1638). (The Scientific Research Projects Coordination Unit of Ordu University).

\section{CONFLICT OF INTEREST}

The author(s) declared no conflicts of interest.

\section{REFERENCES}

1. Sakkas H, Papadopoulou C. Antimicrobial Activity of Basil, Oregano, and Thyme Essential Oils. Journal of Microbiology and Biotechnology. 2017;28(27):429-38.

2. Filip S, Vidović S, Vladić J, Pavlić B, Adamović D, Zeković Z. Chemical composition and antioxidant properties of Ocimum basilicum L. extracts obtained by supercritical carbon dioxide extraction: Drug exhausting method. The Journal of Supercritical Fluids 2016; 109:20-5.

3. Teofilović B, Grujić-Letić N, Goločorbin-Kon S, Stojanović S, Vastag V, Gadžurić S. Experimental and chemometric study of antioxidant capacity of basil (Ocimum basilicum) extracts. Industrial Crops and Products. 2017;100:176-82.
4. Obiri S, Yeboah PO, Osae S, Adu-kumi S, Cobbina SJ, Armah FA et al. Human health risk assessment of artisanal miners exposed to toxic chemicals in water and sediments in the Prestea-Huni Valley District of Ghana. International Journal of Environmental Research and Public Health. 2016;13(1):139.

5. Wu Z, Liu S, Zhao J, Wang F, Du Y, Zou S, et al. Comparative responses to silicon and selenium in relation to antioxidant enzyme system and the glutathione-ascorbate cycle in flowering Chinese cabbage (Brassica campestris L. ssp. chinensis var. utilis) under cadmium stress. Environmental and Experimental Botany. 2017;133:1-11.

6. Michalak A. Phenolic compounds and their antioxidant activity in plants growing under heavy metal stress. Polish Journal of Environmental Studies. 2006;15(4):523-30.

7. Dinakar N, Nagajyothi PC, Suresh S, Udaykiran $\mathrm{Y}$, Damodharam T. Phytotoxicity of cadmium on protein, proline and antioxidant enzyme activities in growing Arachis hypogaea L. seedlings. Journal of Environmental Sciences. 2008;20(2):199-206.

8. Ekmekçi Y, Tanyolac D, Ayhan B. Effects of cadmium on antioxidant enzyme and photosynthetic activities in leaves of two maize cultivars. Journal of Plant Physiology. 2008; 165(6):600-11.

9. Sarker MMR, Nimmi I, Kawsar MH. Preliminary screening of six popular fruits of Bangladesh for in vitro IgM production and proliferation of splenocytes. Bangladesh Pharmaceutical. 2012;15(1):31-7.

10. Abdel-Gadir WS, Mohamed F, Bakhiet AO. Antimicrobial activity of Tamarindus indica fruit and Piper nigrum seed. Research Journal of Microbiology. 2007;2(11):824-30.

11. Ronald MA. Microbiologia. In Compania Editorial Continental SA de CV, México DF. 1990;505.

12. Singleton VL, Rossi JA. Colorimetry of total phenolics with phosphomolybdicphosphotungstic acid reagents. American Journal of Enology and Viticulture. 1965;16(3):144-58.

13. Okem A, Southway C, Stirk WA, Street RA, Finnie JF, Van Staden J. Effect of cadmium and aluminum on growth, metabolite content and biological activity in Drimia elata (Jacq.) Hyacinthaceae. South African Journal of Botany. 2015;98:142-7.

14. McCance KR, Flanigan PM, Quick MM, Niemeyer ED. Influence of plant maturity on anthocyanin concentrations, phenolic composition, and antioxidant properties of 3 purple basil (Ocimum basilicum L.) cultivars. Journal of Food Composition and Analysis. 2016; 53:30-9. 
PICTORIAL ABSTRACT

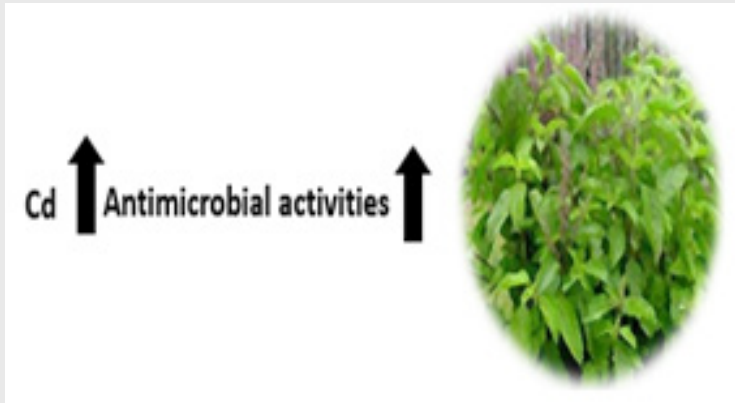

About Authors

\section{SUMMARY}

- Antimicrobial, antioxidant and total phenolic content of basil genotypes were significantly affected by Cd levels.

- Antimicrobial activities of the almost all genotypes were increased with the cadmium increase

- Total phenolic content and DPPH radical scavenging activity values were increased with the $\mathrm{Cd}$ application at low doses.

- Cultivation of basil genotypes in cadmium exposed soil did not cause a significant reduction in total phenolic contents, antioxidant and antimicrobial activities

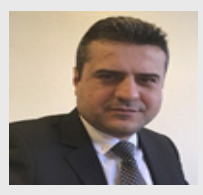

Dr. Kursat Korkmaz: He is presently working as professor at the Department of soil Science and Plant Nutrition in Ordu University. His studies mainly focused on plant nutrition, plant physiology and medicinal and aromatic plant.

Cite this article: Korkmaz K, Ertürk Ö, Ayvaz MC̣, Özcan MM, Akgün M, Kirli A, Alver DO. Effect of Cadmium Application on Antimicrobial, Antioxidant and Total Phenolic Content of Basil Genotypes. Indian J of Pharmaceutical Education and Research. 2018;52(4S):S108-S114. 